\title{
Stock Market Inclusion and Its Connection with Economic Activity in Turkey
}

\author{
Sadik KARAOĞLAN ${ }^{1}$ @ , Mustafa Erhan BILMAN²
}

\begin{abstract}
This study explores the relationship between stock market inclusion and economic activity (liveliness) in Turkey by taking advantage of the recent contributions in causality theory. Stock market inclusion is represented by the seasonally adjusted real stock market trade volume per capita (TV) and economic activity by the seasonally adjusted real gross domestic product per capita (GDP). We use quarterly series covering the period 2003:1-2020:2 and employ asymmetric bootstrap and asymmetric Fourier bootstrap causality testing procedures to obtain robust parameter estimates. Both procedures adopt a nonlinear methodology but the latter is distinguished from the first in the sense that it follows a Fourier series approximation which allows for structural breaks of unknown number, form, and point. Empirical findings suggest that the Fourier-type asymmetric bootstrap causality procedure, thanks to its trigonometric components, captures two unidirectional (one-way) causalities; one running from the positive components of TV to those of GDP and the other running from the negative components of TV to those of GDP, but not vice versa. These findings verified a strong influence on GDP of the alterations i.e. positive and negative shocks in stock market conditions.
\end{abstract}

Key words: Stock market inclusion, economic activity, asymmetric bootstrap causality, Fourier series approximation

JEL classification: C22, E44, E61, G10

\section{Introduction}

The linkage between the financial markets and economic activity has been established by the famous work of Schumpeter long ago in 1911 (Schumpeter, 1911). Schumpeter claims that the development of the financial markets and banks combined with well-organized regulatory and supervisory financial institutions would facilitate the distribution of productive capital among the most efficient users, which in turn enhance economic growth and thus real income. This argument is later acknowledged by other studies such as Gurley and Shaw (1955), Goldsmith (1969), McKinnon (1973), and Shaw (1973), which are regarded as milestones in the literature. The positive influence of financial development on overall economic activity or real income, or on its distribution is still finding a widespread support even today [see, Azman-Saini et al. (2010), Bumann et al. (2013), Samargandi et al. (2015), Shahbaz et al. (2015),
Caporale et al. (2015), Kandil et al. (2017), and most recently Asteriou and Spanos (2019), among others].

Stock markets have promising shares in the financial markets of the developing nations. Besides, stock market development is considered as one of the major indicators affecting economic growth [see, Demirgüç-Kunt and Levine (2001)]. As a developing nation, Turkey is not an exception when it comes to the figures depicting the improving share of Turkey's stock markets in its entire financial system. The course of improvement with respect to the Turkish stock market is illustrated by Table 1. Depending on the annual reports of Borsa İstanbul (BIST) published in 2018 and 2019, i.e. BIST (2018 and 2019), total value of stocks traded in BIST increases from 1993 billion TL in 2018 to 2130 billion TL in 2019. When we consider that the total trade value for BIST more than doubled from 7800 billion TL in 2018 to 19800 billion TL in 2019, we may conclude that there still is a room for improvement for the stock market's share in 
total value traded of BIST. The daily average stock value traded likewise rises from 7.9 billion TL to 8.5 billion TL between 2018 and 2019. The total market value of Turkish stock market is showing progress too: It jumped from 795 billion TL in 2018 to 1100 billion TL in 2019, which correspond to $21.3 \%$ and $25.9 \%$, respectively as the shares in Turkish gross domestic product. These figures place the stock market of Turkey to the $21^{\text {st }}$ rank among the entire global stock markets in both 2018 and 2019 , verifying a stable global course.

This study investigates the relationship between stock market inclusion and economic activity, i.e. real per capita GDP in Turkey to put an emphasis on the linkage between the financial and real sectors of the Turkish economy. As stated above, the vast amount of studies in the related literature deal generally with the link between several financial development indicators and real economic activity, i.e. real income and/or its distribution. These studies mostly utilized "financial depth" measures such as the share of total credits to private sector, or that of total deposits in private and state-owned banks, or alternatively that of short-term financial liabilities in real GDP to mimic financial development. However, De la Torre et al. (2017), and TCMB (2011) stressed that the concept of financial development has multifaceted qualitative dimensions beyond financial depth, which can better be understood by financial inclusion. This study takes financial inclusion as access to stock markets depending on the importance of stock markets in Turkish financial system, illustrated above.

Our study is distinguished from the vast number of earlier empirical works for the reason that it adopts asymmetric bootstrap and asymmetric Fourier bootstrap causality testing procedures to obtain robust parameter estimates, and thus a reliable outcome. Both causality procedures follow a nonlinear methodology, but the one with a Fourier series approximation is distinguished from the other on the grounds that it allows for structural breaks of unknown number, form, and point thanks to its trigonometric components. Perron (1989) is the pioneering study which initially proved that structural breaks are very important components of a time series as they change the pattern (the mean and/or the time trend), namely the behavior of a series. The omission of breaks would lead to biased parameter estimates. For this reason, we followed two different causality procedures that allow for nonlinearities and structural breaks, which generally represent the true behavior of real life data series. As far as the authors of the present paper are concerned there is no previous study in the related literature that follows the comparative nonlinear causality framework adopted here. The rest of the paper is organized as follows. Second section provides a review of the recent literature. Third section depicts the data and source of the data. Fourth section explains the econometric methodologies. Fifth section illustrates the estimation results and makes an inference. And finally the sixth section concludes.

\section{Literature review}

The empirical literature on the nexus between financial inclusion and economic growth is exceedingly large. Besides, a wide range of dimensions have been added recently by the incorporation of new research questions such as those regarding poverty reduction, financial stability, firm size, natural resource-based economies, various development indices, and gender equality into the issue. It is worthwhile to note that the literature depicted here primarily focuses on the empirical papers that investigate the association between financial inclusion and economic growth or real income.

Table 1: Outlook of Turkey's Stock Market in Retrospect

\begin{tabular}{llllllll}
\hline Indicators (in billion TL) & $\mathbf{2 0 1 3}$ & $\mathbf{2 0 1 4}$ & $\mathbf{2 0 1 5}$ & $\mathbf{2 0 1 6}$ & $\mathbf{2 0 1 7}$ & $\mathbf{2 0 1 8}$ & $\mathbf{2 0 1 9}$ \\
\hline Total value traded & 815 & 873 & 1026 & 1014 & 1468 & 1993 & 2130 \\
\hline Average daily value traded & 3.3 & 3.5 & 4.1 & 4 & 5.9 & 7.9 & 8.5 \\
\hline Total value traded in BIST & 7900 & 9000 & 11894 & 13018 & 6967 & 7800 & 19800 \\
\hline Total market value & 503.7 & 627 & 555 & 614 & 880 & 795 & 1100 \\
\hline Total market value/ GDP (\%) & 27.6 & 31 & 21.5 & 26 & 28.3 & 21.5 & 25.9 \\
\hline Number of firms listed & 421 & 422 & 429 & 405 & 411 & 416 & 402 \\
\hline Share of international investors (\%) & 62.5 & 64 & 62.4 & $64^{*}$ & 66 & 65 & 61 \\
\hline
\end{tabular}

Note: The values are gathered by the authors from the annual reports of BIST published between 2013 and 2019, which are available on BIST's website "borsaistanbul.com". Symbol * implies that the value is calculated by the authors. 
The literature on the positive effects on economic activity of different forms of financial inclusion is quite thick. Burgess and Pande (2005) documented that an increased financial inclusion would lead to a corresponding rise in real incomes and thus help reduce poverty in India. More specifically, they discovered by using data for the period 1977-1990 that rural poverty is alleviated as the public banks keep extending loans to rural regions of India. Andrianaivo and Kpodar (2011) investigated whether financial inclusion promotes economic performance in a sample of 44 African nations. They found a positive relationship between the two variables by adopting a GMM estimator. Inoue and Hamori (2016) conducted an investigation for 37 Sub-Saharan African countries by using data for 20042012. Their findings revealed that an improvement in the number of commercial bank branches fosters economic growth. Likewise, Kim et al. (2018) examines the connection between financial inclusion and economic growth for a sample of $55 \mathrm{OIC}$ countries. They also conclude by using their findings from dynamic panel models, panel VAR estimations, and panel Granger causality tests that the first has a positive impact on the latter. Park and Mercado (2018) made a global analysis by using a data set for 176 countries to evaluate the inclusion-poverty and income inequality linkage. They report a strong correlation between a heightened financial inclusion and a lessened poverty and income inequality worldwide. Dawood et al. (2019) reports similar findings for the Indonesian economy. According to their findings, lifting the obstructions in front of free access to financial means would help lower poverty. Inoue (2019) employed a GMM approach and a data set covering the period between 1973 and 2004 to assess the relationship between poverty level and financial access in India. Their results unveiled that together with financial depth, inclusion has a positive impact on poverty reduction. Most recently, Huang et al. (2021) investigated by using a panel model and a data set for 1995-2015, the effect of access, depth, efficiency, and the overall development of financial institutions on economic growth in a sample of $27 \mathrm{EU}$ nations, which comprises the low- and high-income countries as well as new and old member states as sub-samples. Their findings showed that the impact is positive for all country groups analyzed.

The flip side of the literature is represented by the studies evidencing that financial inclusion is either detrimental to or at best ineffective on economic performance. As a leading empirical study, Arestis et al. (2001) found evidence via a time series analysis in favor of the view that the previous cross-country studies may have exaggerated the positive impact of stock market access and development on economic growth rates. They report that the positive link is insignificant even in the advanced economies such as the US and the UK. In addition, they put that risks (or volatility) associated with the stock markets lead to negative growth dynamics in the UK, France, and Japan. Naceur and Ghazouani (2007) explored the correlations between bank and stock market development and economic growth by using a data set for 11 MENA region countries and employing a GMM estimator. They find that there is no significant relationship between bank or stock market development and economic activity. Moreover, they proved that the impact of bank development on economic growth is even negative having controlled for the stock market development. Barajas et al. (2013) investigated whether the favorable impact of financial deepening and access on economic growth varies across regions, income levels, and types of the economies by using a data set for 150 countries which covers the period 19752005. They found that the impact is heterogeneous at the international level. More specifically, their findings uncovered that oil-exporting and low-income nations make do with a smaller improvement in economic performance associated with an increased banking depth and stock market activity. They put that this unpleasant outcome appears due to lack of competition, efficiency, progress, and quality in the financial intermediation. Bhattarai (2015) is another pessimist study as it stresses that too much financial deepening and inclusion, which is defined by over-financing by using several financial deepening ratios, may lead to inefficiencies combined with fluctuations in the growth rates of the economies which in turn bring instability to both financial and real sectors. They put the argument by shedding light on the distinction between over-financed yet shrinking developed economies such as Germany, France, UK, USA, and Japan following the 2008 global financial crises and two largest emerging economies, namely China and India, who grew much faster during the post-crisis period despite the fact that they displayed a more discreet stance in financial deepening.

\section{Data}

Stock market inclusion is measured as the seasonally adjusted real stock market trade volume per capita (TV) and economic activity as the seasonally adjusted real gross domestic product per capita (GDP). We use quarterly series covering the period 2003:1-2020:2. The series, descriptive statistics and correlation coefficients 
of which are shown in Table 2 and Table 3 respectively, are gathered from TCMB's online database. The individual series TV and GDP are visually observable in Figure 1 and Figure 2, respectively.

Table 2: Descriptive Statistics for TV and GDP Series

\begin{tabular}{lcc}
\hline & TV & GDP \\
\hline Mean & 2.746259 & 7.832110 \\
\hline Median & 2.756540 & 7.841055 \\
\hline Maximum & 4.525811 & 8.108382 \\
\hline Minimum & 1.054181 & 7.455156 \\
\hline Std. Dev. & 0.534348 & 0.168382 \\
\hline Skewness & -0.359500 & -0.208370 \\
\hline Kurtosis & 5.518304 & 2.109598 \\
\hline Observations & 70 & 70 \\
\hline
\end{tabular}

It is apparent from Table 2 that both TV and GDP series have positive mean and median values. The range for the values of the TV series is larger than that of the GDP. This finding is verified by the fact that the volatility value for the first is almost 3.2 times larger than that for the latter, i.e. 0.53 and 0.17 , respectively. The skewness and kurtosis values for a normally distributed data series are equal to 0 and 3 , or near values respectively. Negative values for skewness imply a left-skewed distribution (with a longer left tail), which is the case for both TV and GDP series. As for kurtosis, since the values for TV and GDP are far from being around 3 , one can conclude that these series do not exhibit a standard normal distribution.

Table 3: Correlation between TV and GDP Series

\begin{tabular}{lcc}
\hline & TV & GDP \\
\hline TV & 1 & 0.5335 \\
\hline GDP & 0.5335 & 1 \\
\hline
\end{tabular}

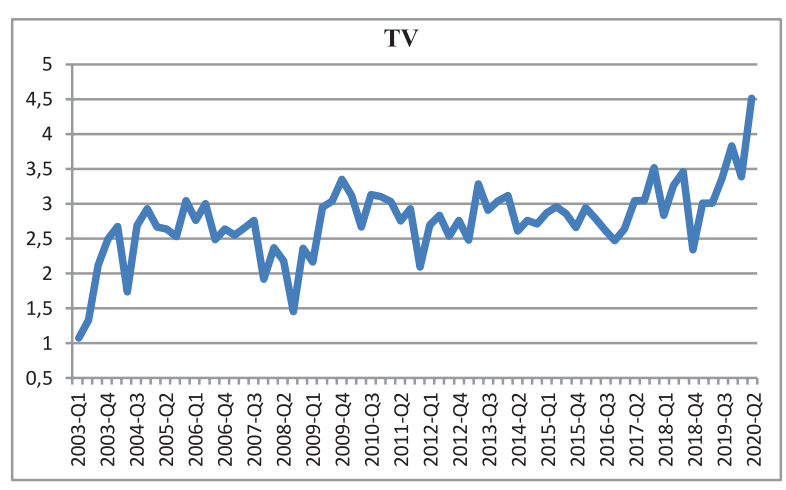

Figure 1:TV series: 2003:1-2020:2

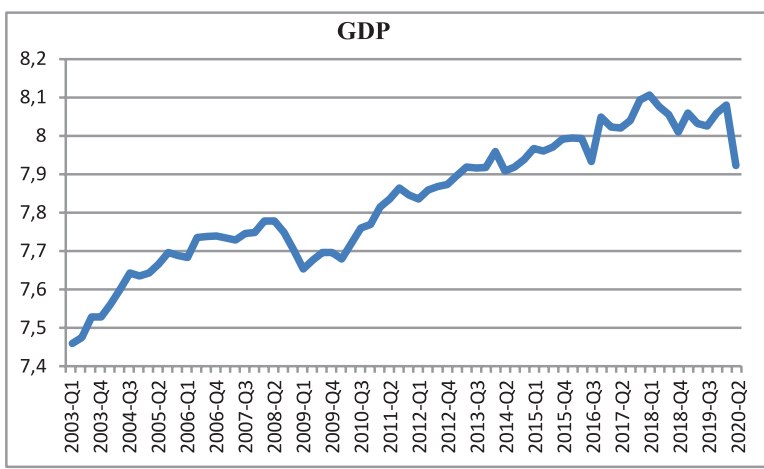

Figure 2: GDP series: 2003:1-2020:2

Figure 1 evidences that TV series represents a volatile behavior against time. In Figure 2 , we see that there are two major structural shifts in GDP following 2008 and 2020, which correspond to the global financial crisis and the Covid-19 pandemic, respectively.

\section{Econometric methodology: Causality tests}

\subsection{Asymmetric bootstrap causality test}

Causality tests in econometrics date back to 1969 when C. W. J. Granger proposed an estimation methodology, where a time series is regressed on its own as well as on a second variable's lagged values. Sims (1972), Hsiao (1981), Toda and Yamamoto (1995), and Hacker and Hatemi-J (2006) are among the leading papers contributed to the causality literature. However, they share the same shortcoming that effects of both favorable and unfavorable developments on the variables are treated evenly i.e. symmetrically in those procedures. In real life, positive and negative shocks or events lead to asymmetric effects instead on both financial and real sectors of a national economy.

Granger and Yoon (2002) is the first study which put forward that the association between two time series could be quite different from those between the cumulative positive and/or negative components of those series. To put it clearly, two time series may not prove to be cointegrated, but they may respond to negative and/or positive events simultaneously. To clarify this property, they separated the series into positive and negative components and acknowledged that there may well be a "hidden"long-run relationship, i.e. a hidden cointegration, between the negative and/ or the positive components of those series. Hatemi-J (2012) applied this asymmetric cointegration logic of Granger and Yoon (2002) into the causality framework. Likewise, they search for a similar hidden association 
between the negative and positive components of two time series, even when there is no causality at all between the level of these series themselves.

Let variables $y_{1 t}$ and $y_{2 t}$ be two integrated series, between which we are searching for a causality relationship. Hatemi-J (2012) defines them as random walk processes shown by Eq. (1) and Eq. (2).

$$
\begin{aligned}
& y_{1 t}=y_{1 t-1}+\varepsilon_{1 t}=y_{10}+\sum_{i=1}^{t} \varepsilon_{1 i} \\
& y_{2 t}=y_{2 t-1}+\varepsilon_{2 t}=y_{20}+\sum_{i=1}^{t} \varepsilon_{2 i}
\end{aligned}
$$

where $t=1,2, \ldots T$; the constants $y_{10}$ and $y_{20}$ represent the initial values; and $\varepsilon_{1 i}$ and $\varepsilon_{2 i}$ symbolize white-noise disturbances. Positive and negative components of the variables are read as follows:

$$
\begin{aligned}
& \varepsilon_{1 i}^{+}=\max \left(\varepsilon_{1 i}, 0\right), \varepsilon_{2 i}^{+}=\max \left(\varepsilon_{2 i}, 0\right) \text { (for positive shocks) } \\
& \varepsilon_{1 i}^{-}=\min \left(\varepsilon_{1 i}, 0\right), \varepsilon_{2 i}^{-}=\min \left(\varepsilon_{2 i}, 0\right) \text { (for negative shocks) }
\end{aligned}
$$

So, we can rewrite the series as the combinations of the positive and negative components as follows [i.e. Eq. (4) and (5)]:

$$
\begin{aligned}
& \varepsilon_{1 i}=\varepsilon_{1 i}^{+}+\varepsilon_{1 i}^{-} \\
& \varepsilon_{2 i}=\varepsilon_{2 i}^{+}+\varepsilon_{2 i}^{-}
\end{aligned}
$$

Substituting Eq. (4) and (5) into Eq. (1) and (2), respectively yields Eq. (6) and (7) below.

$$
\begin{aligned}
& y_{1 t}=y_{1 t-1}+\varepsilon_{1 t}=y_{10}+\sum_{i=1}^{t} \varepsilon_{1 i}^{+}+\sum_{i=1}^{t} \varepsilon_{1 i}^{-} \\
& y_{2 t}=y_{2 t-1}+\varepsilon_{2 t}=y_{20}+\sum_{i=1}^{t} \varepsilon_{2 i}^{+}+\sum_{i=1}^{t} \varepsilon_{2 i}^{-}
\end{aligned}
$$

Consequently, the positive and negative shocks can be written in a cumulative form as follows: $y_{1 t}^{+}=\sum_{i=1}^{t} \varepsilon_{1 i}^{+}, y_{1 t}^{-}=\sum_{i=1}^{t} \varepsilon_{1 i}^{-}, y_{2 t}^{+}=\sum_{i=1}^{t} \varepsilon_{2 i}^{+}$, and $y_{2 t}^{-}=\sum_{i=1}^{t} \varepsilon_{2 i}^{-}$.

Hatemi-J (2012) stressed that, by definition, positive and negative shocks would have permanent effects on the variables in question. Having constructed the above framework, he then estimates the causal association between the cumulative positive components as well as the cumulative negative components of the variables. Hatemi-J (2012) notes also that other potential causalities between the components can be tested in the further studies. Having presumed that $y_{t}^{+}=\left(y_{1 t}^{+}, y_{2 t}^{+}\right)$, and $y_{t}^{-}=\left(y_{1 t}^{-}, y_{2 t}^{-}\right)$a vector autoregressive model of order $p$, i.e. $\operatorname{VAR}(p)$. can be employed to determine the causal relationships. It is displayed in Eq. (8) and (9) below.

$$
\begin{aligned}
& y_{t}^{+}=a+A_{1} y_{t-1}^{+}+\cdots+A_{p} y_{t-p}^{+}+u_{t}^{+} \\
& y_{t}^{-}=\beta+\gamma_{1} y_{t-1}^{-}+\cdots+\gamma_{p} y_{t-p}^{-}+\omega_{t}^{-}
\end{aligned}
$$

where $y_{t}^{+}$and $y_{t}^{-}$stand for the $2 \times 1$ vectors of the variables, $a$ and $\beta$ are the $2 \times 1$ vectors of intercepts, and $u_{t}^{+}$and $\omega_{t}^{-}$represent $2 \times 1$ vectors of error terms that match the positive and negative cumulative components of the variables, respectively. The matrices $A_{r}$ and $\gamma_{r}$ are $2 \times 1$ matrices of coefficients for lag order $r(r=1, \ldots, p)$. Hatemi-J (2012) introduces the following information criterion to choose the optimal lag length $(p)$ :

$$
H J C=\ln \left(\left|\widehat{\Omega}_{j}\right|\right)+j\left(\frac{n^{2} \ln T+2 n^{2} \ln (\ln T)}{2 T}\right), \quad j=0, \ldots, p .
$$

In eq. (10), $T$ stands for the sample size, and $n$ represents the number of equations in the VAR system. $\left|\widehat{\Omega}_{j}\right|$ is the determinant of the estimated variance-covariance matrix of the error terms in the VAR system depending on the lag length $j$. Having picked the optimal lag length, the following two null hypotheses are tested: " $k^{\text {th }}$ element of $y_{t}^{+}$does not Granger cause the $m^{\text {th }}$ element of $y_{t}^{+}$", and " $l^{\text {th }}$ element of $y_{t}^{-}$does not Granger cause the $f^{t h}$ element of $y_{t}^{-\prime}$. A Wald-type test is performed, which is defined as follows:

$$
\begin{aligned}
& Y:=\left(y_{1}^{+}, \ldots, y_{T}^{+}\right) \quad(n \times T) \text { matrix, } \\
& D:=\left(a, A_{1}, \ldots, A_{p}\right) \quad(n \times(1+n p)) \text { matrix, } \\
& Z:=\left[\begin{array}{c}
1 \\
y_{t}^{+} \\
y_{t-1}^{+} \\
\vdots \\
y_{t-p+1}^{+}
\end{array}\right]((1+n p) \times 1) \text { matrix, for } t=1, \ldots, T ; \\
& Z:=\left(Z_{0}, \ldots, Z_{T-1}\right) \quad((1+n p) \times T) \text { matrix, and } \\
& \delta:=\left(u_{1}^{+}, \ldots, u_{T}^{+}\right) \quad(n \times T) \text { matrix. }
\end{aligned}
$$

In the final step, the $\operatorname{VAR}(p)$ system is written in a compact form as in Eq. (11).

$$
Y=D Z+\delta
$$

Wald's test methodology is employed to test the null of non-Granger causality, i.e. $H_{0}: C \emptyset=0$.

$$
\text { Wald }=(C \emptyset)^{\prime}\left[C\left(\left(Z^{\prime} Z\right)^{-1} \otimes S_{U}\right) C^{\prime}\right]^{-1}(C \varnothing),
$$

In Eq. (12), $\varnothing=\operatorname{vec}(D)$, and vec implies the column-stacking operator; $\otimes$ stands for the Kronecker product, and $C$ is a matrix of $p \times n(1+n p)$, the elements of which are one for restricted parameters and zero for the remaining parameters. $S_{U}$ shows the variance-covariance matrix of the unrestricted VAR system, which is estimated as follows: $S_{U}=\frac{\widehat{\delta}_{U}^{\prime} \hat{\delta}_{U}}{T-q}$, where $q$ is the number of parameters in each equation in the VAR system. The Wald statistic depicted above will have an asymptotic chi-square distribution with degrees of 
freedom equal to the number of restrictions to be tested, i.e. $p$, as long as the normal distribution is satisfied. Hatemi-J (2012) emphasized that real-life financial data generally follow a non-normal distribution. To resolve this problem, he obtains the critical values by utilizing bootstrap simulations.

\subsection{Fourier-type asymmetric bootstrap causality test}

Enders and Jones (2016) note that it is useful to use time dummies in order to estimate the precise point and magnitude of the structural break, when that break is sharp. If the structural break is smooth, an alternative approach is needed. Enders and Jones (2016) developed, by following Gallant (1981), a flexible Fourier series approximation shown in Eq. (13). They substitute the trigonometric components into the conventional Granger (1969) causality equations, which are illustrated in Eq. (14). $n$ in Eq. (13), stands for the highest number of breaks that can be found in a data series such as $y_{t}$. However, identifying a large value for $n$ generally corresponds to a case where the stochastic parameters change, which brings about a fall in the degrees of freedom and an over-parameterized (over-fitted) model. For this reason, as suggested by Becker, Enders, and Lee (2006), a single-frequency Fourier series component, displayed by Eq. (14), can be preferred which has a stronger potential to capture the breaks of indefinite number, form, and point in the deterministic trend of the series.

$$
\begin{aligned}
& d(t)=a_{0}+\sum_{k=1}^{n} a_{1 k} \sin \left(\frac{2 \pi k t}{T}\right)+\sum_{k=1}^{n} b_{1 k} \cos \left(\frac{2 \pi k t}{T}\right) \\
& d(t)=a_{0}+a_{1} \sin \left(\frac{2 \pi k t}{T}\right)+b_{1} \cos \left(\frac{2 \pi k t}{T}\right)
\end{aligned}
$$

where $k$ represents the number of frequencies in the Fourier function that minimizes the sum of squared residuals. $t$ shows the trend component; $T$ symbolizes the number of observations; and $\pi$ is identical to 3.1416.

In addition, Nazlıŏlu et al. (2016) suggested superimposing the same Fourier series approximation into Toda and Yamamoto's (1995) causality testing procedure, which is represented by Eq. (15). Note that
Eq. (15) redefines $y_{t}$ in such a way as to make it reflect the gradual structural changes of unknown number, form, and point thanks to $d(t)$, the time-dependent constant parameter. Note also that these structural changes in $y_{t}$ are disregarded, namely the constant parameter is presumed as fixed (time-independent), in a conventional VAR system.

Yılancı et al. (2019) developed the asymmetric Fourier causality test, which is a hybrid of the methodologies put forward by Hatemi-J (2012) and Nazlıoğlu et al. (2016). This study follows Yılancı et al. (2019) and estimates Eq. (16) and (17) and reports the estimation results in the next section. In Eq. (15), (16), and (17); $p$ shows the optimal number of lags in the VAR system, and dmax, the maximal integration order of the variables.

\section{Empirical findings and inference}

Depending on the suggestion of Dolado and Lütkepohl (1996) we did not determine the integration orders, i.e. time series properties, of the variables by unit root testing procedures prior to the formal causality tests applied in this study. The same approach is followed more recently by an applied study by Yılancl and Bozoklu (2014). Findings from the asymmetric bootstrap causality test, which are reported in Table 4, suggest that there is causal linkage neither among the positive nor the negative components of TV and those of GDP series running in any direction. In other words, the asymmetric causality test failed to confirm any causality relationship between either the negative or the positive shocks in reference to the variables under investigation.

However, when the findings from the asymmetric bootstrap causality test with a Fourier series approximation are concerned there exist two causal connections: The first, running from the positive shocks of TV to those of GDP and the latter, from the negative shocks of TV to those of GDP, but not vice versa. This result acknowledges that the Fourier-type asymmetric bootstrap test captures a hidden causality basically running from TV to GDP, but not vice versa, when structural breaks of unknown number $(k)$, form, and date are allowed for.

$$
\begin{aligned}
& y_{t}=a_{0}+a_{1} \sin \left(\frac{2 \pi k t}{T}\right)+b_{1} \cos \left(\frac{2 \pi k t}{T}\right)+\beta_{1} y_{t-1}+\cdots+\beta_{p+d} y_{t-(p+d)}+\varepsilon_{t} \\
& Y_{t}=\beta_{0}+\beta_{1} \sin \left(\frac{2 \pi k t}{T}\right)+\beta_{2} \cos \left(\frac{2 \pi k t}{T}\right)+\sum_{i=1}^{p+d_{\max }} \theta_{i} Y_{t-i}+\sum_{i=1}^{p+d_{\max }} \delta_{i} X_{t-i}+\varepsilon_{t} \\
& X_{t}=\gamma_{0}+\gamma_{1} \sin \left(\frac{2 \pi k t}{T}\right)+\gamma_{2} \cos \left(\frac{2 \pi k t}{T}\right)+\sum_{i=1}^{p+d_{\max }} \tau_{i} Y_{t-i}+\sum_{i=1}^{p+d_{\max }} \varphi_{i} X_{t-i}+u_{t}
\end{aligned}
$$


Table 4: Asymmetric Bootstrap Causality Test Results

\begin{tabular}{|c|c|c|c|c|c|c|c|}
\hline \multirow{2}{*}{ Procedure } & & \multirow{2}{*}{ Null } & \multirow{2}{*}{ Test statistic } & \multicolumn{4}{|c|}{ Critical Value } \\
\hline & & & & $p$ & $1 \%$ & $5 \%$ & $\% 10$ \\
\hline \multirow{4}{*}{$\begin{array}{l}\text { Asymmetric causality test } \\
\text { (Hatemi-J, 2012) }\end{array}$} & \multirow{2}{*}{$\begin{array}{l}T V \neq> \\
G D P\end{array}$} & $T V^{+} \neq>G D P^{+}$ & 2.161 & 1 & 8.105 & 4.198 & 2.893 \\
\hline & & $T V^{-} \neq>G D P^{-}$ & 1.298 & 1 & 8.297 & 4.181 & 2.717 \\
\hline & \multirow{2}{*}{$\begin{array}{l}G D P \neq> \\
T V\end{array}$} & $G D P^{+} \neq>T V^{+}$ & 0.292 & 1 & 8.207 & 4.073 & 2.779 \\
\hline & & $G D P^{-} \neq>T V^{-}$ & 0.005 & 1 & 9.082 & 4.156 & 2.678 \\
\hline
\end{tabular}

Note: $p$, determined by the Hatemi-J Criterion (HJC), shows the optimal lag length of the VAR model. Symbols $*^{* * *}$, and ${ }^{* * *}$ stand for statistical significance at $10 \%, 5 \%$, and $1 \%$, respectively. $X \neq>Y$ implies the null of " $X$ does not Granger cause $Y^{\prime \prime}$.

Table 5: Asymmetric Fourier Bootstrap Causality Test Results

\begin{tabular}{|c|c|c|c|c|c|c|c|}
\hline Procedure & & Null & $\begin{array}{l}\text { Wald } \\
\text { statistic }\end{array}$ & $\begin{array}{l}\text { Bootstrap } \\
\text { Probability }\end{array}$ & $\begin{array}{l}\text { Optimal } \\
\text { lag length }\end{array}$ & $\begin{array}{l}\text { Optimal } \\
\text { frequency } \\
\text { number }(\boldsymbol{k})\end{array}$ & dmax \\
\hline \multirow{4}{*}{$\begin{array}{l}\text { (Yilanci et al. } \\
\text { 2019) }\end{array}$} & \multirow{4}{*}{$\begin{array}{l}\text { Asymmetric } \\
\text { Fourier } \\
\text { causality test }\end{array}$} & $T V^{+} \neq>G D P^{+}$ & 48.630 & $0.000^{* * *}$ & 9 & 3 & 1 \\
\hline & & $T V^{-} \neq>G D P^{-}$ & 27.510 & $0.010^{* *}$ & 9 & 3 & 1 \\
\hline & & $G D P^{+} \neq>T V^{+}$ & 12.533 & 0.240 & 9 & 3 & 1 \\
\hline & & $G D P^{-} \neq>T V^{-}$ & 13.374 & 0.198 & 9 & 3 & 1 \\
\hline
\end{tabular}

Note: One additional lag is imposed into the VAR system as dmax. Symbols ${ }^{*},{ }^{* *}$, and ${ }^{* * *}$ stand for statistical significance at $10 \%, 5 \%$, and $1 \%$, respectively. $X \neq>Y$ implies the null of " $X$ does not Granger cause $Y$ ".

\section{Conclusion and economic policy suggestions}

In this paper we examine the causal relationship between stock market inclusion and economic activity in Turkey. We hypothesize that any positive and/or negative development in Turkish stock market inclusion may lead to respectively a positive and/or a negative development in the real economy. In other words, we postulate that there are causal linkages between the financial and real sectors in Turkey.

Stock market inclusion is measured as the seasonally adjusted real stock market trade volume per capita (TV) and economic activity as the seasonally adjusted real gross domestic product per capita (GDP). Quarterly series covering the period 2003:1-2020:2 are used and asymmetric bootstrap and asymmetric Fourier bootstrap causality testing procedures are employed to obtain robust parameter estimates. Both procedures follow a nonlinear form but the latter is distinguished from the first in the sense that it utilizes a Fourier series approximation which allows for structural breaks of unknown number, form, and point.

The findings from our empirical analyses are quite interesting. The asymmetric bootstrap causality test without the Fourier series approximation failed to capture any causality in any direction among the positive and negative components of TV and those of GDP. However, thanks to its trigonometric components which allow for structural breaks of indefinite point, number and form, the Fourier-type asymmetric causality test verified that there exist two unidirectional causal linkages between TV and GDP: The first linkage running from the positive components of TV to those of GDP and the second linkage running from the negative components of TV to those of GDP, but not vice versa.

These results unveiled that a strong hidden causality exists between the positive and negative developments regarding the TV and those concerning the GDP, respectively. To put it more specifically, positive and negative shocks in TV represent causal associations that justify respectively the positive and negative developments in GDP. Our findings are consistent with the argument that stock market (or financial) inclusion induces economic activity. More specifically, the findings from the asymmetric Fourier bootstrap causality procedure are supported by Burgess and Pande (2005), Dawood et al. (2019) and Inoue (2019) who also found a positive connection between stock market and financial development or inclusion and economic performance in different individual emerging market economies like Turkey. Our findings are consistent also with the following studies which adopted panel data settings with samples of developing or developed nations: 
Andrianaivo and Kpodar (2011), Inoue and Hamori (2016), Kim et al. (2018), Park and Mercado (2018), and Huang et al. (2021).

The major policy suggestion that follows from the findings is that the policy makers in Turkey should consider the fact that the policies that stimulate stock market inclusion would also trigger improvements, namely positive growth dynamics, in real GDP of Turkey. Besides, they also have to take into consideration that a negative policy shock affecting the stock market inclusion would also set off a corresponding negative effect on the real economic activity. 


\section{References}

Andrianaivo, Mihasonirina \& Kangni, Kpodar. (2011). ICT, Financial Inclusion, and Growth: Evidence from African Countries. IMF WP 11/73.

Arestis, P., Demetriades, P. O., \& Luintel, K. B. (2001). Financial development and economic growth: The role of stock markets. Journal of Money, Credit and Banking. Vol. 33, No. 1, pp. 16-41.

Asteriou, D., \& Spanos, K. (2019). The relationship between financial development and economic growth during the recent crisis: Evidence from the EU. Finance Research Letters, 28, 238-245.

Azman-Saini, W. N. W., \& Law, S. H. (2010). FDI and economic growth: New evidence on the role of financial markets. Economics letters, 107(2), 211-213.

Barajas, Adolfo., Ralph Chami., \& Seyed Reza, Yousefi. (2013). The Finance and Growth Nexus Re-Examined: Do All Countries Benefit Equally? IMF WP/13/130.

Becker, R., Enders, W., \& Lee, J. (2006). A stationarity test in the presence of an unknown number of smooth breaks. Journal of Time Series Analysis, 27(3), 381-409.

Bhattarai, Keshab. (2015). Financial Deepening and Economic Growth in Advanced and Emerging Economies. Review of Development Economics. 19(1), 178-195.

Borsa İstanbul. (2018). Faaliyet raporu, https://borsaistanbul. com/files/borsa-istanbul-2018-entegre-faaliyet-raporu. pdf (25.10.2020)

Borsa İstanbul. (2019). Faaliyet raporu, https://borsaistanbul. com/files/borsa-istanbul-2019-entegre-faaliyet-raporu. pdf (26.10.2020)

Bumann, S., Hermes, N., \& Lensink, R. (2013). Financial liberalization and economic growth: A meta-analysis. Journal of International Money and Finance, 33, 255-281.

Burgess, Robin, and Rohini, Pande. (2005). “Do Rural Banks Matter? Evidence from the Indian Social Banking Experiment." American Economic Review, 95 (3): 780-795.

Caporale, G. M., Rault, C., Sova, A. D., \& Sova, R. (2015). Financial development and economic growth: Evidence from 10 new European Union members. International Journal of Finance \& Economics, 20(1), 48-60.

Dawood, T.C., Pratama, H., Masbar, R., \& Effendi, R. (2019). Does financial inclusion alleviate household poverty? Empirical evidence from Indonesia. Econ. Sociol. 12 (2), 235-252.

De la Torre, A., Gozzi, J. C., \& Schmukler, S. L. (2017). Innovative Experiences in Access to Finance : Market-Friendly Roles for the Visible Hand? Latin American Development Forum; Washington, DC: World Bank. https://openknowledge. worldbank.org/handle/10986/27529 License: CC BY 3.0 IGO.
Demirguc-Kunt, A., \& Levine, R. (2001). Financial structure and economic growth: Perspectives and lessons. Financial structure and economic growth: A cross-country comparison of banks, markets, and development, 3-14.

Dolado, J. J., \& Lütkepohl, H. (1996). Making Wald tests work for cointegrated VAR systems. Econometric Reviews, 15(4), 369-386.

Enders, W., \& Jones, P. (2016). Grain prices, oil prices, and multiple smooth breaks in a VAR. Studies in Nonlinear Dynamics \& Econometrics, 20(4), 399-419.

Gallant, A. R. (1981). On the bias in flexible functional forms and an essentially unbiased form: the Fourier flexible form. Journal of Econometrics, 15(2), 211-245.

Goldsmith, R. W. (1969). Financial Structure and Development. New Haven: Yale University Press.

Granger, C.W.J. (1969). Investigating causal relations by econometric models and cross-spectral methods. Econometrica: Journal of the Econometric Society, 424-438.

Granger, C.W.J., \& Yoon, G. (2002) "Hidden Cointegration" Department of Economics Working Paper University of California, No:2002-02.

Gurley, J. G., \& Shaw, E. S. (1955). Financial Aspects of Economic Development. The American Economic Review, 45(4), 515538.

Hacker, R.S., \& Hatemi-J, A. (2006) “Tests for Causality between Integrated Variables Using Asymptotic and Bootstrap Distributions: Theory and Application" Applied Economics, 38(13):1489-1500.

Hatemi-J, A. (2012) "Asymmetric Causality Tests with an Application" Empirical Economics, 43(1):447-456.

Hsiao, C. (1981) "Autoregressive Modelling and Money-Income Causality Detection" Journal of Monetary Economics, 7(1): 85-106.

Huang, Ruixian., Seenaiah Kale., Sudharshan Reddy Paramati., $\&$ Farhad Taghizadeh-Hesary. (2021). Recent trends in economic research:The nexus between financial inclusion and economic development: Comparison of old and new EU member countries. Economic Analysis and Policy. 69, 1-15.

Inoue, Takeshi. (2019), "Financial inclusion and poverty reduction in India", Journal of Financial Economic Policy. Vol. 11, No. 1, pp. 21-33.

Inoue, Takeshi \& Shigeyuki, Hamori. (2016). Financial Access and Economic Growth: Evidence from Sub-Saharan Africa. Emerging Markets Finance and Trade. 52:3, 743-753.

Kandil, M., Shahbaz, M., Mahalik, M. K., \& Nguyen, D. K. (2017). The drivers of economic growth in China and India: globalization or financial development?. International Journal of Development Issues. 
Kim, Dai-Won., Jung-SukYu., \& M. Kabir Hassan. (2018). Financial inclusion and economic growth in OIC countries. Research in International Business and Finance. 43, 1-14.

McKinnon, R. I. (1973). Money and Capital in Economic Development. Washington: Brookings Institution Press.

Naceur, S.B., \& Samir, G. (2007). Stock markets, banks, and economic growth: Empirical evidence from the MENA region. Research in International Business and Finance. 21, 297-315.

Nazlioglu, S., Gormus, N. A., \& Soytas, U. (2016). Oil prices and real estate investment trusts (REITs): Gradual-shift causality and volatility transmission analysis. Energy Economics, 60, 168-175.

Park, C.Y., \& Mercado, Jr., R. (2018). Financial inclusion, poverty, and income inequality. Singap. Econ. Rev. 63 (01), 185-206.

Perron, P. (1989). The great crash, the oil price shock, and the unit root hypothesis. Econometrica: journal of the Econometric Society, 1361-1401.

Samargandi, N., Fidrmuc, J., \& Ghosh, S. (2015). Is the relationship between financial development and economic growth monotonic? Evidence from a sample of middle-income countries. World development, 68, 66-81.

Schumpeter, J. (1911). The theory of economic development. Harvard Economic Studies. Vol. XLVI.
Shahbaz, M., Rehman, I. U., \& Muzaffar, A. T. (2015). Re-Visiting Financial Development and Economic Growth Nexus: The Role of Capitalization in B angladesh. South African Journal of Economics, 83(3), 452-471.

Shaw, E. S. (1973). Financial Deepening in Economic Development. New York: Oxford University Press.

Sims, C.A. (1972) "Money, Income, and Causality" American Economic Review, 62(4): 540-552.

TCMB (2011). Dünyada ve Türkiye'de Finansal Hizmetlere Erişim ve Finansal Eğitim. https://www.tcmb.gov.tr/wps/wcm/ connect/362bbf12-7d95-47eb-9d4d-13039893ce5e/ finansal_egitim.pdf?MOD=AJPERES\&CACHEID=ROOTWORKSPACE-362bbf12-7d95-47eb-9d4d-13039893ce5e -m3fBalY

Toda, H.Y., \& Yamamoto, T. (1995) "Statistical Inference in Vector Autoregressions with Possibly Integrated Processes" Journal of Econometrics, 66(1- 2):225-250.

Yilanci, V., \& Bozoklu, Ş. (2014). Türk sermaye piyasasında fiyat ve işlem hacmi ilişkisi: Zamanla Değişen Asimetrik Nedensellik Analizi. Ege Academic Review, 14(2).

Yılancı, V., Özgür, Ö., \& Görüş, M. Ş. (2019). The asymmetric effects of foreign direct investment on clean energy consumption in BRICS countries: A recently introduced hidden cointegration test. Journal of Cleaner Production, 237, 117786. 